\title{
On Application of Principle of Non Bis in Idem to Continuous Crime
}

\author{
Wei Gu \\ Department of National Defense Economy, Army Logistic University of PLA, No.122, Luojiadun \\ Community, Qiaokou District, Wuhan City, Hubei Province, China, 430035 \\ rayyar456@163.com
}

Keywords: Principle of non bis in idem, Principle of prohibition against double jeopardy, One crime of essence, One determining crime.

\begin{abstract}
As an ancient principle of legal proceeding and originated in Roman law, the principle of the non bis in idem has been widely adopted by the two legal system countries and become an international standard for criminal proceedings. The two legal system countries have different standards for the definition of the principle of "the same crime" and "one action". And the application of the principle is also different. The continuous crime is a unique concept of the continental law system which is admitted in the theory of criminal law in China. At the same time, the theory of the criminal law in China also recognizes the crime of successive offenses. However, according to the provisions of the criminal law, it is possible to carry out several crimes together with a conviction for "contingency". There are concurrence and conflict of the penalty method of the continuous crime and the principle of the non bis in idem which should be made as the basic principle of criminal procedure in China. When a certain crime act is regarded and sentenced by the court as a continuous crime according to the provisions of the criminal law, whether during the execution of the penalty or the prosecution period after the execution of the penalty is completed, if the court finds that the crime has missed part of the criminal act, it shall no longer be omitted.
\end{abstract}

\section{Introduction}

As an ancient principle of legal proceeding, the principle of non bis in idem originates in Roman law. After thousands of years of development, it has been widely adopted by the two legal system countries and has become an international standard for criminal proceedings. The International Covenant on Civil and Political Rights also affirms the principle. China signed the Convention on October 5, 1998 and from then on it led to the upsurge of research on this principle by the Chinese theoretical community. However, the Chinese theoretical community has not done enough research on how to apply this principle in practice. For example, as one crime of essence and one determining crime, the continuous crime has a great deal of particularity in the application of the principle of Non Bis in idem. In this regard, the two legal system countries have a completely different way of handling it and yet there is no unified plan in China. For this reason, on the basis of comparing the different ways of dealing with the continuous crime in the two legal system countries, this paper attempts to explore the appropriate approach for the application of the principle of non bis in idem to the continuous crime.

\section{Origin, development and type of the principle of non bis in idem}

As the basic law of the ancient Rome trial system, in the two A.D., "Prohibit twice prosecution" was developed by Rome jurists as non bis in idem. ${ }^{[1]}$ That is, the parties may not apply for a retrial for a case that has been formally judged. Because of this, Urbian pointed out in the first series of On the Uriah and Pabbia Law that a settled case was regarded as truth. ${ }^{[2]}$ This principle was first established in civil trials and later in criminal proceedings. On the basis of inheriting the core content of the principle, the two legal system countries integrate their own unique legal concepts and values and 
formed the principle of non bis in idem in the continental law system countries and the principle of prohibition against double jeopardy in the Anglo-American law system countries.

\subsection{Principle of prohibition against double jeopardy in Anglo-American law system countries}

The principle of prohibition against double jeopardy inherits the double meaning of the principle of non bis in idem in ancient Roman law. It has been developed not only after the court has made effective criminal judgment but also in the process of criminal trial. It is not only applicable to the court after the effective criminal judgment being made, but also to the process of criminal trial. It emphasizes that after the defendant has been subjected to a criminal trial, he must not be subject to two prosecutions, trials and scientific punishments for the same crime. The principle of prohibition against double jeopardy is an important constitutional principle in the United States. The legal precedent of the Supreme Court of the United States illustrates the specific meaning of the principle: the same crime is ensured not be re-prosecuted after it is declared innocent, not be prosecuted again after conviction or not be punished again. ${ }^{[3]}$

\subsection{Principle of non bis in idem in the continental law system countries}

The principle of non bis in idem in the continental law system countries requires if an actual judgment of a case has been made, the parties could not sue again and the court should not handle it again unless there are exceptions to the law. It has the following features: Firstly, it is based on the effective judgment of the court, and only when there is a court's judgment comes into force, does it lead to the application of the principle. Secondly, the court's judgment of guilt and innocence applies the principle, but the pure procedural ones do not apply it. Thirdly, the principle of non-reconciliation is closely related to the res judicata, and plays a role in maintaining it. Lastly, the tenet of the principle is to emphasize the stability of the law. ${ }^{[4]}$

\section{Intention of non bis in idem}

In order to take full account of the situation in the two legal systems, article 14, item 7 of the International Covenant on Civil and Political Rights clearly defines the definition of the principle of non bis in idem that any person who has been convicted or acquitted through a country's laws and criminal procedures must not be tried or punished for the same crime. It is noteworthy that the Convention defines the "one matter" as "the same crime". But whether the "one matter" is "the same crime" or "the same fact" is still not unified in theoretical research or in the practice of various countries. In the continental law system countries, the mainstream view of France is that "one matter" refers to "the same factual behavior" which means that the subject of action between the two prosecutions, the parties to and the reasons for the lawsuit are all the same. In Japan and Taiwan province of China, the "one matter" is defined by the unity and identity of the public prosecution facts. And the unity and identity of the facts of the public prosecution are determined according to the number of the penalty power. The facts related to the right of punishment are collectively referred to as "one matter". In Anglo-American law system countries, the classic expression of "one matter" was the first to stipulate in Article 5 of the U.S. Constitutional Amendment: "..nnor shall any person be subject for the same offense to be twice put in jeopardy of life or limb; ..." In the case of "the same offense", whether it refers to "the same crime fact" or "the same crime", it has not been stipulated in the legislation. In practice, the object of the trial is the cause of action. One sin is a cause of action, and the court cannot go beyond the prosecution for the cause of a crime. The scope of "something" actually means that the cause of action for the former and latter are the same, that is, the crimes are of the same nature. In the United States, the scope of "one matter" is defined by the identity of crimes. The author believes that the value center of the principle of non bis in idem in the modern sense has turned to the protection of the defendant's human rights. If the "one matter" is understood as "the same offense", it means that the public prosecution organ can sue the defendant repeatedly with 
different charges for the same crime facts. Although it helps to correct the judicial errors that have occurred, and ultimately finds the truth of the entity, it makes the defendant fall into the troubles and risks and unrest caused by the lawsuit, and to withstand the procedural burdens beyond his tolerance obligations. It is also contrary to human rights. Therefore in the modern sense, the understanding of "one matter" as "the same fact" is more in line with the value orientation of the principle of non bis in idem. On the definition of "the same fact", the author agrees with the rule of the number of the penalty power. According to the rule, there is only one penalty for a crime. Within the scope of a penalty, the public prosecutor has the obligation to sue all criminal facts. If the criminal facts of the front and back prosecution are included in the right of punishment, the facts of the crime are the same one. Such a definition combines legal actions and de facto actions. After the case is judged and entered into force, the effectiveness of public prosecution is related to the facts of the whole penalty power, and the effectiveness of the trial is also related to the facts involved in the whole penalty power. Within the scope of the facts covered by the power of a penalty, if the prosecutor only sues part of the facts, the court can only retrial some ones, he can no longer make further prosecutions or retrials on the basis of other facts without trial. This definition is similar to the scope of "one matter" in the Anglo-American legal system which means, the causes of action in the front and back complaints are the same.

\section{Penalty Method of continuous crime in two law system countries}

Originated in Italy, as a specific concept in the criminal law of the continental law system, the continuous crime refers to the crimes that are based on the same or generalized criminal intentions, continuous executions of the same nature and violate the same crime. Many countries in the continental law system do not provide specific provisions of the continuous crime in law, but they follow its theory in practice. While in some countries, it is removed after stipulating. The similar criminal behavior of a continuous crime may not be treated in the same way and it is considered to be physically unfair. But the continuous crime undeniable simplifies the lawsuit procedure and saves the lawsuit resources. And it is still recognized by the law of China and many other continental law countries.

In essence, the continuous crime includes several crimes of the same nature and not punished for several crimes. However, the continuous crime is essentially a number of crimes. When some of the facts of a crime are prosecuted and declared guilty, can the rest of the facts be prosecuted and tried again? This involves the question of whether the continuous crime is applicable to the principle of non bis in idem. And it is often discussed in criminal law and criminal procedure law in the continental law system. While in the Anglo-American legal system countries, their criminal laws have long pursued the idea of codification, and there is no conception of the continuous crime and whether they should follow the principle of prohibition against double jeopardy. The continuous crime can be prosecuted and convicted in a number of crimes. ${ }^{[4]}$

\section{Concurrence and conflict of penalty method of continuous crime and principle of non bis in idem in China}

In China, the eighty-ninth article of the criminal law on the limitation of prosecution is the legal basis to recognize the continuous crime which is often dealt with according to the different situations before or after the judgment is declared in the judicial practice.

\subsection{The concurrence of the penalty method of the continuous crime and the principle of the non bis in idem}

At present, the rule of the continuous crime being punished according to one crime is generally accepted and followed in the law theory and judicial practice in China which means that not under the premise of the implementation of graft, should be committed to the actor's crime shall be given a 
heavier punishment or as aggravated punishment discretion. Some of the provisions of the criminal law also demonstrate this attitude. For example, the third paragraph of the 153rd article of the criminal law stipulates if multiple corruption is not handled, it shall be disposed of in accordance with the accumulated amount of it.

This method of punctuation insists on the principle of the principle of the non bis in idem. Just as Mr. Wen WANG, the scholar in Taiwan province of China said. Whether the case is single or not should be judged based on whether the fact of a specific crime and the specific penalties is single. A criminal fact of a defendant is a penalty in the substantive law and a case in the law of the procedure, it is a single case. Therefore, the singleness of the defendant and the fact of the crime are the indispensable elements that constitute a single case. ${ }^{[5]}$ And continuous crime is essentially formed of a number of independent crimes which means a number of criminal acts that constitute a continuous crime can be independent and separate. The mutually independent crimes are based on the same subjective intention and diversity of the continuous implementation of a certain crime. They constitute the relationship of all and part of the relationship. The criminal law stipulates it as a sin, rather than as a separate crime. These independent crimes due to the implementation of a crime with a continuous subjective intention is based on diversity, constitutes an overall and partial relationship. And they are stipulated as a single sin in the criminal law.

\subsection{Insufficiency of penalty methods of continuous crimes and conflict with principle of non bis in idem}

To the continuous crime, after the judgment is pronounced, during the execution of the penalty and when the public prosecutor finds that some of the criminal acts have been omitted from the original judgment, the missing part of the crime acts combining the judgment with the original verdict, are treated and sentenced as an independent criminal conviction. In the prosecution period after the execution of the penalty, if the public prosecution organ finds that the original judgment omitted some of the criminal acts which would be also treated the missing part as an independent crime conviction and be sentenced and the criminals are again executed.

There are obvious problems in this method of punishment. For a number of independent crimes committed by continuous offenders, whether they are all found and prosecuted before the decision is made, or if they are found guilty after the decision, the offender's criminal facts are the same. The only difference is that the perpetrator's criminal facts are found to be different at the time. There is difference between the continuous crimes committed by several independent criminal acts being executed after one judgment and the new judgments made after the discovery of the crime of leakage. It is actually the way that the prosecuting authority associates the prosecution situation with the penalties that the actor must be punished which means the fact that the circumstances other than the perpetrator is taken as the basis of the criminal responsibility of the perpetrator. It is obviously contrary to the principle of criminal responsibility to take the situation other than the perpetrator as one of the basis for the perpetrator to bear the criminal responsibility. It clearly violates the principle of bearing responsibility solely for one's own crime in the criminal law. ${ }^{[6]}$

This method of punishment is also much more different from the principle of non bis in idem. To the crime of a referee, the fact that the crime has not been prosecuted belongs to the same crime in the substantive law as to the fact that the crime has already been prosecuted. There is only one right of penalty and the litigation cannot be divided into several litigation objects to exercise the penalty right. And other criminal facts that have not been prosecuted may not be prosecuted again. For continuous offenders, the number of crimes committed independently as a crime on the referee has only one right of punishment. If some of the crimes are omitted during the prosecution, the omissions should also be included in this penalty. The public prosecutor has no right to sue again, and the court's effectiveness in adjudicating the part of the prosecution will naturally be part of the omission. 


\section{Conclusion}

As an international judicial principle advocated by international conventions, the principle of the non bis in idem cannot be avoided and should not be avoided in China. The author believe that China should draw on the practice of Taiwan province of China and the continental law system countries to clarify the principle of the non bis in idem as the basic principle of China's criminal procedure and further standardize the basic operation mechanism of the principle, so as to better play its guiding role. China should establish the principle of he non bis in idem in the general provisions of the criminal procedure law, and at the same time, clarify the specific provisions of the judgment on the issue of the effectiveness of the judgment in the rules section, so as to ensure the operation of it. When a certain crime act is regarded and sentenced by the court as a continuous crime according to the provisions of the criminal law, whether during the execution of the penalty or the prosecution period after the execution of the penalty is completed, if the court finds that the crime has missed part of the criminal act, it shall no longer be omitted. It is the need to protect the human rights of the offenders, and also a practical way to realize the benefit of the criminal procedure.

\section{References}

[1] Yinghui SONG, The principle of criminal procedure, Beijing: China Legal Publishing House Press, 2003, pp. 156-161.

[2] Youping XIE, The research on international criterion of criminal procedure, Beijing: China Legal Publishing House Press, 2002, pp. 533.

[3] Yu LAI and Lin DONG, On the non bis in idem, Legal System and Social Development, vol.5, pp. 63, 2003.

[4] Xingliang CHEN, Study on the prohibition of repeated evaluation, View of rule of law, vol.6, pp. 23, 1993.

[5] Mingxuan GAO and Kechang MA, The criminal jurisprudence, Beijing: Beijing University Publishing House Press, 2000, pp. 298.

[6] Pusheng CHEN, Research on the dispute of Criminal Procedure Law, Wunan book publishing company, vol. 15, pp. 27-28, 1987. 